\title{
ESTIMATION OF EARLY POSTMORTEM INTERVAL BY BIOCHEMICAL CHANGES IN BRAIN AND LIVER OF RATS USING SOME OXIDANT AND ANTIOXIDANT PARAMETERS
}

\author{
Dr. Afaf Abd El-Raouf Shaaban*, Dr. Islam Mostafa Farrag*, Ass. Prof. Eman Saad \\ Bayoumy** \\ * Lecturer of Forensic Medicine and Clinical Toxicology, Faculty of Medicine for Girls, Al- \\ Azhar University, ** Assistant Professor of Medical Biochemistry, Faculty of Medicine for \\ Girls, Al-Azhar University
}

\begin{abstract}
A precise estimate of the postmortem interval (PMI) is one of the primary tasks in forensic pathology. After death, it cannot be assumed that oxidant/antioxidant balance be adequately controlled by the body, so changes in oxidant/ antioxidant parameters are evaluated as biochemical disturbances. Aim: The aim of this work was to investigate whether the changes in some oxidant and antioxidant parameters can be relied upon in estimating the early PMI (the first 8 hours after death) in rat brain and liver. Methodology: Forty rats were divided into eight groups (five rats each). Rats were sacrificed by cervical dislocation after being anaesthetized by ether inhalation. The head and the abdomen were opened, where both brain and liver were extracted at intervals of one hour $(0-1,1-2,2-3,3-4,4-5,5-6,6-7$ and $7-8$ hours intervals). In brain and liver homogenates, the following parameters were measured; the antioxidant parameters: superoxide dismutase (SOD), Glutathione-S-transferase (GST), Glutathione Reduced (GSH) and catalase (CAT), and the oxidant parameters: Malondialdehyde (MDA) and nitric oxide (NO). These parameters were compared between groups depending on time after death. Results: The results indicated that the oxidative damage started earlier in the brain than in the liver and the antioxidants were affected more early in the brain than in the liver to overcome the oxidant damage occurred. There was a statistical significant negative (inverse) correlation between the time after death (P.M. interval) and all analyzed antioxidants (SOD, GST, RGSH and CAT) in the brain, while in the liver, the correlation was between the time after death (P.M. interval) and one of antioxidant parameters (GST). On the other hand, there was a statistical significant positive (direct) correlation between the time after death (P.M. interval) and all analyzed oxidants (MDA and NO) in both brain and liver. Regression analysis was developed in order to determine the equations for P.M. interval estimation using these parameters individually and in combination which selected by the multiple regression analysis of the statistical program. Conclusion: This study concluded that the oxidants and antioxidants in brain and liver of rats are important in determining the early period (the first 8 hours) after death. The liver was found to be more resistible to oxidative damage than the brain. Using these biochemical markers, it is possible to estimate the early postmortem interval.

Key words: early postmortem interval, oxidants, antioxidants, liver, brain, rats.
\end{abstract}




\section{INTRODUCTION}

Estimation of postmortem interval (PMI), or time since death, is one of the primary tasks for forensic medicine. Knowing PMI helps investigators to reconstruct the circumstances in the case of a suspicious death or homicide (Young et al., 2013).

Accurate estimation of postmortem interval (PMI) has great values to criminal investigation and trial. Estimation of PMI is essential for including and excluding suspects on the basis of their sites at the time of death and provides a time frame in which unrecognized decomposed remains might be related to missing persons (Chandrakanth et al., 2013).

There are several internal factors that affect the postmortem process and make the determination of PMI difficult such as age, sex, physical, physiological and pathological state of the deceased (Prieto-Castelló et al., 2007). In addition, there are external factors including air temperature and humidity as well as animal and insect activity affect the postmortem process, rendering the determination of time of death more complicated (Poloz and O'Day, 2009).

The currently used methods to estimate the PMI are evaluation of physiological and physical postmortem changes, such as the distribution and amount of livor mortis, rigor mortis, changes in body temperature, changes in potassium concentration of the vitreous humor, the degree of decay in the body, proliferation of bugs on the corpse and their developmental stages (Madea and Musshoff, 2007). However, these changes have limitations in PMI determination, due to the bias inflicted by several variables (Vass, 2011).
Other methods such as thanatochemistry: the changes that occur in the chemical composition of the human corpse after death, and molecular techniques have been reported, attempting for a more accurate PMI estimation (Lin et al., 2011). However, all of these methods are still waiting for confirmation by other large studies (Sener et al., 2012).

Over the last few decades, some progress in PMI estimation has been made using biochemical parameters, supported by different statistical approaches (Munoz Barus et al., 2008).

These methods have been shown to be more accurate in PMI estimation, since the effect of external conditions is less relevant than in the currently used traditional methods. Moreover, these changes begin immediately after death, so can be used to estimate the PMI during the first hours after death since most victims are found in this period (Tumram et al., 2011). A combination of traditional and biochemical methods, has been proposed to increase the reliability of PMI estimation and narrow down the margins of error associated with individual analysis (Sener et al., 2012).

In living tissue, there is continuous formation of free radicals, which are reactive chemicals with an unpaired electron in an outer orbit (Chandrakanth et al., 2013). Reactive oxygen species (ROS) comprise both free radical and non free radical oxygen containing molecules such as hydrogen peroxide (H2O2), superoxide $(\mathrm{O} 2-)$, singlet oxygen $(1 / 2 \mathrm{O} 2)$, and the hydroxyl radical $(\mathrm{OH})$. There are also reactive nitrogen, iron, copper, and sulfur species which could attribute to increased ROS formation and oxidative 
stress and impair the redox balance (Donaldson and Lamont, 2014).

Free radicals are produced when cells create energy from food and oxygen and when they are exposed to microbial infections, extensive exercise, or pollutants/toxins such as cigarette smoke, alcohol, ionizing and UV radiations and pesticides (Sharma and Agarwal, 2004). Nitric oxide (NO) is produced in response to homeostatic, inflammatory, or mitogenic stimuli. It can produce hydroxyl radicals as well as nitrogen dioxide radicals (Yao et al., 2004). Malondialdehyde (MDA), a biological marker of oxidative stress, results from peroxidation of the fatty acids containing 3 or more double bounds in cell membranes (Niki et al., 2005).

To cope with the oxidative stress, animal and human cells have developed the antioxidant defense system, which consists of superoxide dismutase (SOD), catalase (CAT), Glutathione-Stransferase (GST) and glutathione reductase (GR) together with a number of low molecular-weight antioxidants such as ascorbate, $\alpha$-tocopherol and glutathione (GSH), cysteine, thioredoxin, vitamins, etc. (Wei et al., 2001).

Superoxide dismutase (SOD) converts superoxide anions into hydrogen peroxide as a subtract for catalase. Catalase (CAT) breaks hydrogen peroxide down into $\mathrm{O} 2$ and $\mathrm{H} 2 \mathrm{O}$ using either an iron or manganese cofactor (Rahman et al., 2012).

Glutathione (GSH) is an endogenous tri-peptide which protects the cells against free radicals either by donating a hydrogen atom or an electron. It is also very important in the regeneration of other antioxidants like ascorbate (Belikov et al., 2015).
Glutathione-S-transferase

(GST) catalyzed reactions of toxic substances through conjugation with GSH protecting the cells from oxidative damage. Glutathione reductase (GR) reduces glutathione from its oxidized to its reduced form, thus recycling it to continue neutralizing more free radicals (Hayyan et al., 2016).

During life, under physiological conditions, the tradeoff between the oxidants and antioxidants balance is in favor of antioxidants (Iraz et al., 2006). In injured tissue, this equilibrium is in favor of oxidants with a decrease in antioxidant levels in the damaged tissues (Sener et al., 2012). After death, it cannot be assumed that oxidant/antioxidant balance be adequately controlled by the body, so changes in oxidant/ antioxidant parameters are evaluated as biochemical disturbances (Abo ElNoor et al., 2016).

\section{AIM OF THE WORK}

The aim of this work is to study the biochemical changes in brain and liver of rats using some oxidants and antioxidants during the early period (the first 8 hours) after death, and to establish possible formulae to estimate early postmortem interval using these parameters.

\section{MATERIALS \& METHODS}

\section{Reagents:}

All reagents were purchased from Biodiagnostic Egypt Chemical Company.

\section{Animals:}

This study was carried out on 40 male albino rats, their body weight ranged from 150 to $200 \mathrm{~g}$ (age, 12 weeks). They were obtained from Helwan animal breeding farm, Cairo, 
Egypt. Animals were maintained in stainless steel cages in a well-ventilated animal house at normal temperature $\left(22^{\circ} \mathrm{C} \pm 5^{\circ} \mathrm{C}\right)$ under a 12 : 12 -hour lightdark cycle. They were fed with normal feeding and given water. They were kept under suitable conditions for one week for adaptation prior to the start of the experiment.

\section{Ethical Considerations:}

The handling of animals was performed according to the rules for the experimental research ethics approved by Research Ethics Committee at faculty of Medicine for Girls Al-Azhar University. Fewer numbers of animals estimated to affair valid results were used. Animal painless procedures conducted with appropriate sedation to avoid pain and stress.

\section{Experimental Design:}

This current work was carried out in Forensic Medicine and Clinical Toxicology Department and Medical Biochemistry Department - Faculty of Medicine for girls, Al-Azhar University- Cairo, Egypt. Rats were divided into eight groups (five rats each). Rats were sacrificed by cervical dislocation after being anaesthetized by ether inhalation. These rats were kept at room temperature and humidity $\left(22^{\circ} \mathrm{C}\right.$, $15 \%)$ during the period between the time of death and organ removal. The head \& the abdomen were opened then brain and liver were extracted at intervals of one hour $(0-1,1-2,2-3,3-$ $4,4-5,5-6,6-7$ and 7-8 hours intervals).

\section{Tissue Preparation:}

After animal dissection, the brain and liver tissues were perfused with a phosphate buffered saline (PBS) solution, $\mathrm{pH} 7.4$ containing $0.16 \mathrm{mg} / \mathrm{ml}$ heparin to remove any red blood cells and clots. Then, tissues were frozen at $-80^{\circ} \mathrm{C}$ until biochemical analysis.

One gram of tissue was homogenized in 5-10 $\mathrm{ml}$ cold buffer (i.e $50 \mathrm{mM}$ potassium phosphate, $\mathrm{pH}$ 7.5.), centrifuged at 4000 r.p.m for 15 minutes under cooling condition, the supernatant was assayed immediately according to each kit instructions.

Biochemical Analysis:

The following markers were measured in liver and brain homogenates using the commercial kits:

A-Antioxidant Parameters

1. Superoxide Dismutase (SOD):

The SOD activity was estimated as described by Nishikimi et al., (1972); the method is based on the ability of SOD to inhibit the reduction of nitroblue tetrazolium (NBT) by superoxide anions generated by pyrogallol autoxidation. One unit of SOD is defined as the amount of enzyme that causes 50\% inhibition of the autoxidation of pyrogallol under assay conditions.

Briefly, $0.1 \mathrm{mg}$ of sample was added to $0.9 \mathrm{ml}$ distilled water and 0.75 $\mathrm{ml}$ ethanol chloroform (2:1). The mixture was centrifuged at $18,000 \mathrm{x} \mathrm{g}$ for $60 \mathrm{~min}$. at $4^{0} \mathrm{C}$. A quantity of 0.25 $\mathrm{ml}$ supernatant was added to $0.5 \mathrm{ml}$ tris- cacodylic buffer PH $8.2 \quad$ (46 $\mathrm{mmol} / \mathrm{L}$ cacodilic acid $+5 \mathrm{mmol} / \mathrm{L}$ diethylene diamine penta acetic acid adjusted by tris- hydroxymethyl amino methane) $+0.1 \mathrm{ml}$ of $16 \%$ triton $\mathrm{X}-100$ $+0.25 \mathrm{ml}$ of $0.98 \mathrm{mmol} / \mathrm{L}$ nitroblue tetrazolium $+10 \mu \mathrm{l}$ of $0.9 \mathrm{mmol} / \mathrm{L}$ pyrogallol/ $1 \mathrm{~mol} / \mathrm{L} \mathrm{HCl}$. The mixture was incubated for 5 minutes at $37^{\circ} \mathrm{C}$, and then the reaction was stopped by adding $0.3 \mathrm{ml}$ of stopper reagent $(2 \mathrm{~mol} / \mathrm{L}$ formic acid in $16 \%$ triton $\mathrm{X}$ - 
100). Optical density (absorbance) was measured at $560 \mathrm{~nm}$ (by spectrophotometer, model: Shimadzu, UV-240IPC, Australia). Results are expressed as $\mathrm{U} / \mathrm{g}$ protein.

2. Glutathione-S-transferase (GST): The total GST activity (cytosolic and microsomal) was measured by UV visible spectrophotometer as described by Habig et al., (1974) by measuring the conjugation of 1- chloro- 2,4dinitrobenzene ( CDNB ) with reduced glutathione. The conjugation is accompanied by an increase in absorbance at $340 \mathrm{~nm}$. The rate of increase is directly proportional to the GST activity. Results are expressed as $\mathrm{U} / \mathrm{mg}$ protein.

3. Glutathione reduced (GSH):

The GSH activity was estimated as described by Beutler et al., (1963). The method based on the reduction of 5,5 dithiobis $(2$ - nitrobenzoic acid) (DTNB) with glutathione (GSH) to produce a yellow compound. The reduced chromogen directly proportional to GSH concentration in the sample and its absorbance can be measured at $405 \mathrm{~nm}$ by the spectrophotometer. Results are expressed as $\mathrm{mol} / \mathrm{g}$ protein.

\section{Catalase (CAT):}

The CAT activity was estimated as described by Aebi, (1984), based on the principle that the disappearance of hydrogen peroxide was monitored spectrophotometrically at $510 \mathrm{~nm}$. One unit of catalase activity is defined as that the amount which decompose 1 $\mu \mathrm{mol}$ of $\mathrm{H} 2 \mathrm{O} 2 / \mathrm{min}$ at $250 \mathrm{C}$ and $\mathrm{pH}$ 7.0. CAT was measured spectrophotometrically at $510 \mathrm{~nm}$ for 1 min. Results are expressed as U/mg protein.

A-Oxidant Parameters
1. Malondialdehyde (MDA):

MDA is measured as described by Ohkawa et al., (1979). This method is based on the measurement of MDA level using the thiobarbituric acid (TBA) test as follows: a $0.5 \mathrm{ml}$ sample was shaken with $2.5 \mathrm{ml}$ of $20 \%$ trichloroacetic acid, to the mixture $1 \mathrm{ml}$ of $0.67 \%$ of TBA was added, shaken, and kept for 30 minutes in a boiling water bath followed by rapid cooling. Then $4 \mathrm{ml}$ of n-butyl alcohol was added and shaken. The mixture was centrifuged at $3000 \mathrm{rpm}$ for 10 minutes. The resultant n-butyl alcohol layer was taken into a separate tube and the MDA was determined colorimetrically from the absorbance at $634 \mathrm{~nm}$. Results are expressed as $\mathrm{nmol} / \mathrm{mg}$ protein).

\section{Nitric Oxide (NO):}

The NO levels were measured according to the method of Montgomery and Dymock, (1961). The method is based on a two-step process. The first step is the conversion of nitrate into nitrite using a nitrate reductase. The second step is the addition of the Griess reagent (consists of sulfanilamide and $\mathrm{N}$-(1-napthyl)ethylenediamine), which converts nitrite into a deep purple azo compound; photometric measurement of absorbance at $540 \mathrm{~nm}$ is due to the fact that this azo chromophore accurately determines nitrite concentration. NO levels were expressed as $\mu \mathrm{mol} / \mathrm{mg}$ protein.

\section{Statistical Analysis:}

Recorded data were analyzed using the statistical package for social sciences, version 20.0 (SPSS Inc., Chicago, Illinois, USA) (Bourke et al., 1985). Quantitative data were expressed as mean \pm standard deviation (SD). Qualitative data were expressed 
as frequency and percentage. The following tests were done:

- A one-way analysis of variance (ANOVA) was used for comparison between different variables.

- Linear regression was used to obtain regression formulae using the time after death (P.M. interval) as the dependent variable. The analyzed oxidants and antioxidants were the independent variables.

- Standard error of the estimate (SEE) was also calculated, it predicts the deviation of estimated from the actual P.M. interval.

- The significance level was set at $\mathrm{P} \leq 0.05$.

\section{RESULTS:}

Comparison of the levels of analyzed oxidants and antioxidants in the brain tissues of rats between groups depending on time after death is illustrated in (Table 1).

There was a statistical significant difference in all parameters between groups. The antioxidant parameters (SOD, GST, GSH and CAT) decreased statistically with time, while the oxidant parameters (MDA and NO) increased statistically with time.

Regarding antioxidants, SOD started to be significantly decreased at 1-2 hours after death, followed by GST (at 2-3 hours), then CAT (at 3-4 hours) and finally GSH (at 5-6 hours).

On the other hand, the oxidant parameter; NO started to be significantly increased at 2-3 hours after death then MDA (at 4-5 hours).

Table (1): ANOVA one way statistical analysis of analyzed oxidants and antioxidants between groups depending on time after death in the brain of rats, data are expressed as Means \pm SD (Standard Deviation):

\begin{tabular}{|c|c|c|c|c|c|c|c|}
\hline \multicolumn{2}{|c|}{$\begin{array}{l}\text { Groups(Time } \\
\text { after death) }\end{array}$} & $\begin{array}{l}\text { SOD } \\
\mathrm{U} / \mathrm{g}\end{array}$ & $\begin{array}{l}\text { GST } \\
\text { U/mg }\end{array}$ & $\begin{array}{l}\text { GSH } \\
\mathrm{mol} / \mathrm{g}\end{array}$ & $\begin{array}{l}\text { CAT } \\
\text { U/mg }\end{array}$ & $\begin{array}{l}\text { MDA } \\
\mathrm{nmol} / \mathrm{g}\end{array}$ & $\begin{array}{l}\text { NO } \\
\mu \mathrm{mol} / \mathrm{g}\end{array}$ \\
\hline \multicolumn{2}{|l|}{ 0-1 hour } & $\begin{array}{l}687.33 \pm 10 \\
8.54\end{array}$ & $\begin{array}{l}145.33 \pm \\
34.02\end{array}$ & $\begin{array}{l}288.33 \pm 6 \\
6.50\end{array}$ & $\begin{array}{l}623.67 \pm 1 \\
45.03\end{array}$ & $\begin{array}{l}7.00 \pm 7.8 \\
1\end{array}$ & $3.50 \pm 0.00$ \\
\hline \multicolumn{2}{|l|}{ 1-2 hour } & $\begin{array}{l}499.67 \pm 10 \\
7.96^{*}\end{array}$ & $\begin{array}{l}124.67 \pm \\
44.28\end{array}$ & $\begin{array}{l}280.67 \pm 1 \\
04.92\end{array}$ & $\begin{array}{l}694.33 \pm 1 \\
72.05\end{array}$ & $\begin{array}{l}10.00 \pm 5 . \\
29\end{array}$ & $6.42 \pm 3.00$ \\
\hline \multicolumn{2}{|l|}{ 2-3 hour } & $\begin{array}{l}406.00 \pm 53 \\
.69 * *\end{array}$ & $\begin{array}{l}82.00 \pm 3 \\
2.14 *\end{array}$ & $\begin{array}{l}206.67 \pm 1 \\
3.28\end{array}$ & $\begin{array}{l}630.67 \pm 4 \\
4.12\end{array}$ & $\begin{array}{l}10.00 \pm 3 . \\
61\end{array}$ & $9.25 \pm 3.13 *$ \\
\hline \multicolumn{2}{|l|}{ 3-4 hour } & $\begin{array}{l}303.67 \pm 12 \\
9.50 * *\end{array}$ & $\begin{array}{l}73.00 \pm 3 \\
1.19 *\end{array}$ & $\begin{array}{l}214.00 \pm 4 \\
6.36\end{array}$ & $\begin{array}{l}391.00 \pm 9 \\
3.82 *\end{array}$ & $\begin{array}{l}12.67 \pm 3 . \\
51\end{array}$ & $12.75 \pm 3.63 * *$ \\
\hline \multicolumn{2}{|l|}{ 4-5 hour } & $\begin{array}{l}176.67 \pm 17 \\
.90^{* *}\end{array}$ & $\begin{array}{l}61.33 \pm 2 \\
.52 * *\end{array}$ & $\begin{array}{l}207.00 \pm 2 \\
5.98\end{array}$ & $\begin{array}{l}255.00 \pm 8 \\
9.02 * *\end{array}$ & $\begin{array}{l}14.67 \pm 1 . \\
15^{*}\end{array}$ & $15.67 \pm 0.52 * *$ \\
\hline \multicolumn{2}{|l|}{ 5-6 hour } & $\begin{array}{l}239.33 \pm 47 \\
.90 * *\end{array}$ & $\begin{array}{l}22.00 \pm 6 \\
.56 * *\end{array}$ & $\begin{array}{l}177.00 \pm 2 \\
2.00 *\end{array}$ & $\begin{array}{l}218.00 \pm 6 \\
1.51 * *\end{array}$ & $\begin{array}{l}15.00 \pm 2 . \\
65^{*}\end{array}$ & $16.00 \pm 0.43^{* *}$ \\
\hline \multicolumn{2}{|l|}{ 6-7 hour } & $\begin{array}{l}245.33 \pm 50 \\
93 * *\end{array}$ & $\begin{array}{l}17.33 \pm 9 \\
.50 * *\end{array}$ & $\begin{array}{l}169.67 \pm 1 \\
2.70 *\end{array}$ & $\begin{array}{l}65.67 \pm 13 \\
.05 * *\end{array}$ & $\begin{array}{l}16.00 \pm 3 . \\
61 *\end{array}$ & $18.08 \pm 1.59 * *$ \\
\hline \multicolumn{2}{|l|}{ 7-8 hour } & $\begin{array}{l}129.67 \pm 55 \\
.08 * *\end{array}$ & $\begin{array}{l}18.33 \pm 1 \\
.53 * *\end{array}$ & $\begin{array}{l}162.33 \pm 6 \\
8.19^{*}\end{array}$ & $\begin{array}{l}53.33 \pm 10 \\
.69 * *\end{array}$ & $\begin{array}{l}17.67 \pm 3 . \\
06 *\end{array}$ & $19.53 \pm 3.55^{* *}$ \\
\hline \multirow{2}{*}{ ANOVA } & $\mathbf{F}$ & 16.143 & 10.813 & 3.322 & 21.824 & 3.165 & 16.664 \\
\hline & p & $<0.001$ & $<0.001$ & 0.047 & $<0.001$ & 0.048 & $<0.001$ \\
\hline
\end{tabular}

*: Significant at $\mathrm{P} \leq 0.05, * *$ : Highly significant at $\mathrm{P} \leq 0.001$, SOD: Superoxide dismutase, GST: Glutathione-S-transferase, GSH: Glutathione reduced, CAT: Catalase, MDA: Malondialdehyde, NO: Nitric oxide, U/g: unit/gram, U/mg: unit/milligram, mol/g: mole/gram, nmol/g: nanomole/gram, $\mu \mathrm{mol} / \mathrm{g}$ : micromole/gram. 
In the liver tissues, comparison of the levels of analyzed oxidants and antioxidants between groups depending on time after death is illustrated in (Table 2).

There was a statistical significant difference between groups in oxidant parameters (MDA and NO) and one of antioxidant parameters (GST). GST decreased statistically with time, while MDA and NO increased statistically with time. There was non-statistical significant difference between groups in other antioxidants (SOD, GSH and CAT).

GST started to be significantly decreased at 2-3 hours after death. On the other hand, both oxidant parameters; NO and MDA started to be significantly increased at 3-4 hours after death.

Table (2): ANOVA one way statistical analysis of analyzed oxidants and antioxidants between groups depending on time after death in the liver of rats, data are expressed as Means $\pm \mathrm{SD}$ (Standard Deviation):

\begin{tabular}{|c|c|c|c|c|c|c|c|}
\hline $\begin{array}{l}\text { Groups } \\
\text { (Time } \\
\text { death ) }\end{array}$ & after & $\begin{array}{l}\text { SOD } \\
\text { U/g }\end{array}$ & $\begin{array}{l}\text { GST } \\
\text { U/mg }\end{array}$ & $\begin{array}{l}\text { GSH } \\
\mathrm{mol} / \mathrm{g}\end{array}$ & $\begin{array}{l}\text { CAT } \\
\text { U/mg }\end{array}$ & $\begin{array}{l}\text { MDA } \\
\mathrm{nmol} / \mathrm{g}\end{array}$ & $\begin{array}{l}\text { NO } \\
\mu \mathrm{mol} / \mathrm{g}\end{array}$ \\
\hline \multicolumn{2}{|l|}{ 0-1 hour } & $\begin{array}{l}2051.67 \pm \\
63.14\end{array}$ & $\begin{array}{l}140.67 \pm \\
51.60\end{array}$ & $\begin{array}{l}40.33 \pm \\
22.90\end{array}$ & $\begin{array}{l}403.67 \pm \\
27.97\end{array}$ & $\begin{array}{l}2.00 \pm 1 \\
.00\end{array}$ & $\begin{array}{l}16.67 \pm 3.6 \\
1\end{array}$ \\
\hline \multicolumn{2}{|l|}{ 1-2 hour } & $\begin{array}{l}1239.00 \pm \\
748.60\end{array}$ & $\begin{array}{l}129.00 \pm \\
14.73\end{array}$ & $\begin{array}{l}32.33 \pm \\
18.50\end{array}$ & $\begin{array}{l}382.67 \pm \\
48.88\end{array}$ & $\begin{array}{l}2.67 \pm \\
2.57\end{array}$ & $\begin{array}{l}21.00 \pm 6.7 \\
3\end{array}$ \\
\hline \multicolumn{2}{|l|}{ 2-3 hour } & $\begin{array}{l}2093.33 \pm \\
345.49\end{array}$ & $\begin{array}{l}76.00 \pm 1 \\
3.75^{*}\end{array}$ & $\begin{array}{l}29.33 \pm \\
16.80\end{array}$ & $\begin{array}{l}347.67 \pm \\
64.05\end{array}$ & $\begin{array}{l}10.00 \pm \\
10.04\end{array}$ & $\begin{array}{l}35.17 \pm 5.0 \\
3\end{array}$ \\
\hline \multicolumn{2}{|l|}{ 3-4 hour } & $\begin{array}{l}2109.33 \pm \\
204.29 \\
\end{array}$ & $\begin{array}{l}73.67 \pm 3 \\
2.72 *\end{array}$ & $\begin{array}{l}29.33 \pm \\
6.35 \\
\end{array}$ & $\begin{array}{l}389.33 \pm \\
85.24\end{array}$ & $\begin{array}{l}20.67 \pm \\
14.87 *\end{array}$ & $\begin{array}{l}42.67 \pm 25 \\
79 *\end{array}$ \\
\hline \multicolumn{2}{|l|}{ 4-5 hour } & $\begin{array}{l}1359.00 \pm \\
469.00\end{array}$ & $\begin{array}{l}48.67 \pm 2 \\
6.03 * *\end{array}$ & $\begin{array}{l}33.00 \pm \\
19.05\end{array}$ & $\begin{array}{l}360.67 \pm \\
204.36\end{array}$ & $\begin{array}{l}21.50 \pm \\
9.34 *\end{array}$ & $\begin{array}{l}42.83 \pm 11 \\
79^{*}\end{array}$ \\
\hline \multicolumn{2}{|l|}{ 5-6 hour } & $\begin{array}{l}1609.00 \pm \\
379.32\end{array}$ & $\begin{array}{l}28.67 \pm 1 \\
7.95^{* *}\end{array}$ & $\begin{array}{l}22.00 \pm \\
11.00\end{array}$ & $\begin{array}{l}378.33 \pm \\
95.45\end{array}$ & $\begin{array}{l}24.50 \pm \\
5.68^{*}\end{array}$ & $\begin{array}{l}50.95 \pm 18 \\
70^{*}\end{array}$ \\
\hline \multicolumn{2}{|l|}{ 6-7 hour } & $\begin{array}{l}2312.00 \pm \\
1031.85\end{array}$ & $\begin{array}{l}23.00 \pm 7 . \\
81 * *\end{array}$ & $\begin{array}{l}19.67 \pm \\
11.72\end{array}$ & $\begin{array}{l}393.67 \pm \\
106.96\end{array}$ & $\begin{array}{l}26.00 \pm \\
15.02 *\end{array}$ & $\begin{array}{l}52.83 \pm 38 \\
23^{*}\end{array}$ \\
\hline \multicolumn{2}{|l|}{ 7-8 hour } & $\begin{array}{l}1843.33 \pm \\
1048.25\end{array}$ & $\begin{array}{l}22.00 \pm 2 \\
8.79 * *\end{array}$ & $\begin{array}{l}14.67 \pm \\
6.35\end{array}$ & $\begin{array}{l}422.33 \pm \\
115.47\end{array}$ & $\begin{array}{l}30.17 \pm \\
15.95^{*}\end{array}$ & $\begin{array}{l}55.07 \pm 21 \\
82 *\end{array}$ \\
\hline \multirow[t]{2}{*}{ ANOVA } & $\mathbf{F}$ & 1.106 & 8.621 & 0.891 & 0.147 & 3.039 & 3.380 \\
\hline & $\mathrm{P}$ & 0.406 & $<0.001$ & 0.536 & 0.992 & 0.031 & 0.049 \\
\hline
\end{tabular}

*: Significant at $\mathrm{P} \leq 0.05, * *$ : Highly significant at $\mathrm{P} \leq 0.001$, SOD: Superoxide dismutase, GST: Glutathione-S-transferase, GSH: Glutathione reduced, CAT: Catalase, MDA: Malondialdehyde, NO: Nitric oxide, U/g: unit/gram, U/mg: unit/milligram, mol/g: mole/gram, nmol/g: nanomole/gram, $\mu \mathrm{mol} / \mathrm{g}:$ micromole/gram.

The correlation between the time after death (P.M. interval) and analyzed oxidants and antioxidants in the brain tissues of rats is illustrated in (Table 3).
There was a statistical significant negative correlation between the time after death (P.M. interval) and all analyzed antioxidants (SOD, GST, GSH and CAT). On the other hand, 
there was a statistical significant positive correlation between the time after death (P.M. interval) and all analyzed oxidants (MDA and NO).

Table (3): Pearson's correlation coefficient for the correlation between the time after death (P.M. interval) and analyzed oxidants and antioxidants in the brain tissues of rats:

\begin{tabular}{|l|l|l|}
\hline Variables & $\begin{array}{l}\text { Correlation } \\
\text { coefficient }(\mathbf{r})\end{array}$ & P-value \\
\hline SOD $(\mathrm{U} / \mathrm{g})$ & -0.294 & $<0.001^{* *}$ \\
\hline GST $(\mathrm{U} / \mathrm{mg})$ & -0.880 & $<0.001^{* *}$ \\
\hline GSH $(\mathrm{mol} / \mathrm{g})$ & -0.852 & $<0.001^{* *}$ \\
\hline CAT $(\mathrm{U} / \mathrm{mg})$ & -0.921 & $<0.001^{* *}$ \\
\hline MDA $(\mathrm{nmol} / \mathrm{g})$ & 0.362 & $<0.001^{* *}$ \\
\hline NO $(\mathrm{umol} / \mathrm{g})$ & 0.914 & $<0.001^{* *}$ \\
\hline
\end{tabular}

*: Significant at $\mathrm{P} \leq 0.05, * *$ : Highly significant at $\mathrm{P} \leq 0.001$, SOD: Superoxide dismutase,

GST: Glutathione $\mathrm{S}$ transferase, GSH: Glutathione reduced, CAT: Catalase, MDA:

Malondialdehyde, NO: Nitric oxide, U/g: unit/gram, U/mg: unit/milligram, mol/g: mole/gram, nmol/g: nanomole/gram, $\mu \mathrm{mol} / \mathrm{g}:$ micromole/gram.

In the liver tissues, the correlation between the time after death (P.M. interval) and analyzed oxidants and antioxidants is illustrated in (Table 4).

There was a statistical significant negative correlation between the time after death (P.M. interval) and one of antioxidant parameters (GST), no correlation was found between the time after death (P.M. interval) and other antioxidants (SOD, GSH and CAT). On the other hand, there was a statistical significant positive correlation between the time after death (P.M. interval) and all analyzed oxidants (MDA and NO).

Table (4): Pearson's correlation coefficient for the correlation between the time after death (P.M. interval) and analyzed oxidants and antioxidants in the liver tissues of rats:

\begin{tabular}{|l|l|l|}
\hline Variables & $\begin{array}{l}\text { Correlation } \\
\text { coefficient }(\mathbf{r})\end{array}$ & P-value \\
\hline SOD $(\mathrm{U} / \mathrm{g})$ & 0.073 & 0.734 \\
\hline GST $(\mathrm{U} / \mathrm{mg})$ & -0.851 & $<\mathbf{0 . 0 0 1}^{* *}$ \\
\hline GSH $(\mathrm{mol} / \mathrm{g})$ & -0.201 & 0.078 \\
\hline CAT $(\mathrm{U} / \mathrm{mg})$ & 0.076 & 0.724 \\
\hline MDA $(\mathrm{nmol} / \mathrm{g})$ & 0.363 & $\mathbf{0 . 0 1 1}$ \\
\hline NO $(\mathrm{umol} / \mathrm{g})$ & 0.427 & $\mathbf{0 . 0 0 4}$ \\
\hline
\end{tabular}

$*$ : Significant at $\mathrm{P} \leq 0.05, * *$ : Highly significant at $\mathrm{P} \leq 0.001$, SOD: Superoxide dismutase,

GST: Glutathione-S-transferase, GSH: Glutathione reduced, CAT: Catalase, MDA:

Malondialdehyde, NO: Nitric oxide, U/g: unit/gram, U/mg: unit/milligram, mol/g: mole/gram, nmol/g: nanomole/gram, $\mu \mathrm{mol} / \mathrm{g}:$ micromole/gram. 
In order to determine the equations for estimation of the time after death (P.M. interval) in the brain and liver of rats using the analyzed oxidants and antioxidants, regression analysis was developed using these parameters individually and in combination (selected by the multiple regression analysis of the statistical program).
In the brain, there was a statistical significant correlation between the time after death (P.M. interval) and all analyzed antioxidants (SOD, GST, GSH and CAT) and oxidants (MDA and NO), so regression analysis was developed using these parameters (Table 5).

Table (5): Regression equations for estimation of the time after death (P.M. interval) in the brain tissues of rats using analyzed oxidants and antioxidants:

\begin{tabular}{|c|c|c|c|c|}
\hline $\begin{array}{l}\text { Independent } \\
\text { variables }\end{array}$ & Regression formula & SEE & $\begin{array}{l}\text { Correlation } \\
\text { coefficient } \\
\text { (r) }\end{array}$ & P-value \\
\hline SOD $(\mathrm{U} / \mathrm{g})$ & $\mathrm{PMI}=(-0.011 \mathrm{SOD})+8.033$ & 1.093 & -0.294 & $<0.001 * *$ \\
\hline GST (U/mg) & $\mathrm{PMI}=(-0.040 \mathrm{GST})+7.233$ & 0.005 & -0.880 & $<0.001 * *$ \\
\hline GSH $(\mathrm{mol} / \mathrm{g})$ & $\mathrm{PMI}=(-0.024 \mathrm{GSH})+9.625$ & 0.006 & -0.852 & $<0.001 * *$ \\
\hline CAT (U/mg) & $\mathrm{PMI}=(-0.008 \mathrm{CAT})+7.522$ & 0.001 & -0.921 & $<0.001 * *$ \\
\hline MDA (nmol/g) & $\mathrm{PMI}=(0.323 \mathrm{MDA})+0.338$ & 0.073 & 0.362 & $<0.001 * *$ \\
\hline NO $(\mu \mathrm{mol} / \mathrm{g})$ & $\mathrm{PMI}=(0.368 \mathrm{NO})-0.157$ & 0.003 & 0.914 & $<0.001 * *$ \\
\hline $\begin{array}{r}\text { Combination } \\
\text { of variables }\end{array}$ & $\begin{array}{l}\mathrm{PMI}=(-0.003 \mathrm{CAT})+(0.130 \\
\mathrm{NO})+4.852\end{array}$ & 0.001 & .901 & $<0.001 * *$ \\
\hline
\end{tabular}

SEE: Standard Error of Estimate, **: Highly significant at $\mathrm{P} \leq 0.001, \mathrm{SOD}$ : Superoxide dismutase, GST: Glutathione-S-transferase, GSH: Glutathione reduced, CAT: Catalase, MDA: Malondialdehyde, NO: Nitric oxide, U/g: unit/gram, U/mg: unit/milligram, mol/g: mole/gram, nmol/g: nanomole/gram, $\mu \mathrm{mol} / \mathrm{g}$ : micromole/gram.

In the liver, there was a statistically significant correlation between the time after death (P.M. interval) and one of antioxidant parameters (GST), and all analyzed oxidants (MDA and NO), so regression analysis was developed using these parameters (Table 6).

Table (6): Regression equations for estimation of the time after death (P.M. interval) in the liver tissues of rats using analyzed oxidants and antioxidants:

\begin{tabular}{|c|c|c|c|c|}
\hline $\begin{array}{l}\text { Independent } \\
\text { variables }\end{array}$ & Regression formula & SEE & $\begin{array}{l}\text { Correlation } \\
\text { coefficient } \\
\text { (r) }\end{array}$ & P-value \\
\hline GST(U/mg) & $\mathrm{PMI}=(-0.040 \mathrm{GST})+7.197$ & 0.005 & -0.851 & $<0.001 * *$ \\
\hline MDA $(\mathrm{nmol} / \mathrm{g})$ & $\mathrm{PMI}=(0.124 \mathrm{MDA})+2.367$ & 0.025 & 0.363 & $0.011 *$ \\
\hline $\mathbf{N O}(\mu \mathrm{mol} / \mathrm{g})$ & $\mathrm{PMI}=(0.063 \mathrm{NO})+2.096$ & 0.020 & 0.427 & $0.004 *$ \\
\hline $\begin{array}{r}\text { Combination } \\
\text { of variables }\end{array}$ & $\begin{array}{l}\mathrm{PMI}=(-0.028 \mathrm{GST})+(0.013 \\
\mathrm{NO})+5.038\end{array}$ & 0.002 & 0.787 & $<0.001 * *$ \\
\hline
\end{tabular}

SEE: Standard Error of Estimate, ${ }^{*}$ : Significant at $\mathrm{P} \leq 0.05, * *$ : Highly significant at $\mathrm{P} \leq$ 0.001, GST: Glutathione-S-transferase, MDA: Malondialdehyde, NO: Nitric oxide, U/mg: unit/milligram, nmol/g: nanomole/gram, $\mu \mathrm{mol} / \mathrm{g}$ : micromole/gram. 


\section{DISCUSSION:}

An accurate estimation of the PMI requires the evaluation of parameters that correlate with time after death. This definition fits well in postmortem changes of biochemical parameters، since each change has its own time factor (Sampaio-Silva et al., 2013).

The oxidant/antioxidant defense system in human body is characterized by the formation of free radicals and their removal by means of antioxidant system. Increase in oxidant levels and a decrease in antioxidant levels are observed in the damaged tissues (Iraz et al., 2006). After death it cannot be proposed that the oxidant/antioxidant equilibrium be controlled sufficiently by the body, thus no matter how much viability the cells show in the early hours of death (Aguilar et al., 2007).

Few studies regarding whether a significant relationship exists between oxidant and antioxidant parameters and the early postmortem interval have been found in the literature.

The aim of this study was to investigate whether the changes in some oxidant and antioxidant parameters can be relied upon in estimating the early PMI (the first 8 hours after death) in rat brain and liver.

In the present study, regarding antioxidants, superoxide dismutase (SOD) started to decrease significantly at 1-2 hours post-mortem in the brain. In the liver, no significant decrease was observed during the period of experiment ( 8 hours). The results of the present study disagree with those of Harish et al., (2011) who measured different oxidant/antioxidant markers in human brain tissue and showed no significant alteration in SOD activity with increasing PMI. Sener et al., (2012) partially agree with our results, who observed a significant decrease in rat liver SOD at 2 to 3 hours postmortem.

The fact that SOD is high in $0-1$ hour of death is explained on the basis that, an aerobic medium is sufficient for SOD to exert its antioxidant activity in this hour in the liver, later when enzymatic degradation by lytic enzymes starts in the liver, SOD starts to decrease (Scarpelli and Iannaccone, 1990).

With respect to Glutathione-Stransferase (GST) level, the present study found a statistically significant decrease at 2-3 hours after death in both brain and liver. These findings partially coincide with those of Sener et al., (2012) who found that the decrease in rat liver GST became significant at 1 to 2 hours postmortem. Meanwhile, skeletal muscles showed significant decrease at 2 to 3 hours postmortem in the study by Ozturk et al., (2013).

The observations of the current study conform to those of Abo ElNoor et al., (2016) who found that GST level decreased significantly at 2 to 3 and 3 to 4 hours after death in the heart and kidney, respectively.

In the present study, glutathione reduced (GSH) started to be significantly decreased at 5-6 hours in the brain. In the liver, no significant decrease was observed during the period of experiment ( 8 hours). Sener et al., (2012) found that the decrease in rat liver became significant at 4 to 5 hours postmortem.

Enzyme GST catalyzed reactions of toxic substances through conjugation with GSH protecting the cells from oxidative damage (Yilmaz et al., 2012, Sharma et al., 2004) 
The delay in GSH decrease after death might rely on the induction of ligase enzyme expression by 4hydroxy-2-nonenal. Investigations have documented that 4-hydroxy-2- nonenal performs de novo synthesis of GSH from amino acids (Liu et al., 1998).

In the present study, catalase (CAT) level was found to be significantly decreased at 3-4 hours after death in the brain. In the liver, no significant decrease was observed during the period of experiment ( 8 hours). This may be due to presence of high concentrations of CAT in the erythrocytes, liver and kidney, whereas lower concentrations are found in the skeletal muscle, brain, and heart (Li et al., 2006).

Sener et al., (2012) found that the decrease in CAT level in rat liver became significant at 1 to 2 hours postmortem. Abo El-Noor et al., (2016) found that catalase level significantly decreased at 1 to 2 and 6 to 7 hours after death in the heart and kidney, respectively.

The results of the present study disagree with those of Harish et al., (2011) who stated that, human brain tissue showed no significant alteration in CAT activity with increasing PMI.

In the present study, regarding oxidant parameters, nitric oxide (NO) started to increase significantly at 2-3 hours after death in brain tissue, and at 3-4 hours in liver tissue after death, while Malondialdehyde (MDA) started to increase significantly at 4-5 hours in brain tissue and at 3-4 hours in the liver tissue after death.

The increased MDA levels with increasing PMI is attributed to increased lipid peroxidation which in turn leads to increased binding and detoxification by GSH that is eventually reduced (Harish et al., 2011).

These findings are in accordance with those of Sener et al., (2012), who found that both NO and MDA started to be significantly increased at 3-4 hours in liver tissue after death.

In a study conducted by Abo ElNoor et al., (2016), it was found that NO was significantly increased at 4 to 5 hours in heart tissue and at 5 to 6 hours in kidney tissue after death. Meanwhile, MDA started to be significantly increased at 3 to 4 hours in the heart tissue and at 5 to 6 hours in the kidney tissue after death.

From the current results, it was observed that oxidative damage started earlier in the brain than in the liver. This could be explained on the basis of difference of antioxidant activities of both organs.

The present study revealed that the antioxidants were affected more early in the brain than in the liver to overcome the oxidant damage occurred. The difference in the enzyme responses may be in part due to the differences in the amount, nature, and activities of these enzymes in the different tissues. The low activity of some antioxidant enzymes in the liver seems to be a result not only of tissue structure oxidative damage, but also of damage of enzymatic structure, function, and enzymatic gene expression (Szymonik-Lesiuk et al., 2003).

In the present study on considering the results of Pearson's correlation coefficient, there was a statistical significant negative (inverse) correlation between the time after death (P.M. interval) and all analyzed antioxidants (SOD, GST, GSH and $\mathrm{CAT}$ ) in the brain, while in the liver, 
the correlation was between the time after death (P.M. interval) and one of antioxidant parameters (GST).

On the other hand, there was a statistical significant positive (direct) correlation between the time after death (P.M. interval) and all analyzed oxidants (MDA and NO) in both brain and liver.

Regression analysis was developed in order to determine the equations for P.M. interval estimation using these parameters individually and in combination which selected by the multiple regression analysis of the statistical program.

The time after death (P.M. interval) was taken as the dependent variable. The analyzed oxidants and antioxidants were the independent variables. Standard error of the estimate (SEE) was also calculated, it predicts the deviation of estimated from the actual P.M. interval.

In the brain, as regards individual parameter, the lowest SEE (the most significant predictor) was found with CAT (0.001) followed by the following ascending order NO (0.003), GST (0.005), GSH (0.006), MDA (0.073), SOD (1.093) (the highest SEE). The statistical program chose combination between CAT and NO as the most significant predictor for P.M. interval estimation in rat brain $(\mathrm{SEE}=0.001)$.

In the liver, considering individual parameter, the lowest SEE (the most significant predictor) was found with GST (0.005) followed by NO (0.020), the highest SEE (the least significant predictor) was found with MDA (0.025). The statistical program chose combination between GST and NO as the most significant predictor for P.M. interval estimation in rat liver $(\mathrm{SEE}=$ 0.002).

Sener et al., (2012) found that SOD, GST and NO were found to be the most significant factors effecting prediction of the P.M. interval in rat liver.

In the study of Abo El-Noor et al., (2016), it was found that GR (glutathione reductase), MDA and TSH (total thiol) are the most significant factors effecting prediction of the early P.M. interval in rat kidney, while in the heart, MDA, NO, and GR were found to be significant factors independently effecting prediction of the early P.M. interval.

\section{CONCLUSION:}

The results of this study indicate that the oxidants and antioxidants in brain and liver of rats change significantly in the first 8 hours after death. The liver was found to be more resistible to oxidative damage than the brain. Using these biochemical markers to derive linear regression formulae can be helpful in detecting the early postmortem interval.

\section{RECOMMENDATIONS:}

Further research and studies are needed taking in consideration the postmortem autolytic process related factors, such as the cause and manner of death, temperature, air humidity and environmental conditions which are not examined in this study.

Significant results were found in this animal study. Therefore, these parameters are recommended to be a subject of further studies on animals for longer duration (more than 8 hours), and on humans. 


\section{REFERENCES}

Abo El-Noor, M.M.; Elhosary, N.M.; Khedr, N.F. and El-Desouky, K.I. (2016): Estimation of Early Postmortem Interval Through Biochemical and Pathological Changes in Rat Heart and Kidney. Am J Forensic Med Pathol, 37(1): 40-46.

Aebi, H. (1984): Catalase in vitro. Methods Enzymol, 105: 121-126.

Aguilar, A.; Alvarez-Vijande, R.; Capdevila, S.; Alcoberro, J. and Alcaraz, A. (2007): Antioxidant patterns (superoxide dismutase; glutathione reductase; and glutathione peroxidase) in kidneys from non-heart-beating-donors: experimental study. Transplant Proc, 39(1): 249-252.

Belikov, A.V.; Schraven, B. and Simeoni, L. (2015): $T$ cells and reactive oxygen species. Journal of Biomedical Science, 22: 85.

Beutler, E.; Duron, O. and Kelly, M.B. (1963): Improved method for the determination of blood glutathione. J Lab Clin Med, 61: 882-8.

Bourke, G.; Daly, L.E. and McGilvary, J. (1985): Interpretation and Uses of Medical Statistics (3rd ed.); London; Blackwell Scientific Publications. :10-105.

Chandrakanth, H.V.; Kanchan, T.; Balaraj, B.M.; Virupaksha, H.S. and Chandrashekar, T.N. (2013): Postmortem vitreous chemistryan evaluation of sodium; potassium and chloride levels in estimation of time since death (during the first 36 $\mathrm{h}$ after death). J Forensic Leg Med, 20(4): 211-216.

Donaldson, A.E. and Lamont, I.L. (2014): Estimation of post-mortem interval using biochemical markers. Aust J Forensic Sci, 46(1): 8-26.

Habig, W.H.; Palost, M.J. and Jakopy, W.B. (1974): GlutathioneS-transferase. The first enzymatic step in mercapturic acid formation. J Biol Chem, 244: 7130-7139.

Harish, G.; Venkateshappa, C.; Mahadevan, A.; Pruthi, N.; Bharath, M.M.S. and Shankar, S.K. (2011): Glutathione metabolism is modulated by postmortem interval; gender difference and agonal state in postmortem human brains. Neurochemistry International, 59: 1029-1042.

Hayyan, M.; Hashim, M.A. and AlNashef, I.M. (2016): Superoxide Ion: Generation and Chemical Implications. Chem Rev, 116 (5): 3029-3085.

Iraz, M.; Ozerol, E.; Gulec, M.; Tasdemir, S.; Idiz, N.; Fadillioglu, E.; Naziroglu, M. and Akyol, O. (2006): Protective effect of caffeic acid phenethyl ester (CAPE) administration on cisplatin-induced oxidative damage to liver in rat. Cell Biochem Funct, 24(4): 357-361.

Li, G.; Sang, N. and Guo, D. (2006): Oxidative damage induced in hearts; kidneys and spleens of mice by landfill leachate. Chemosphere, 65(6):1058-1063.

Lin, X.; Yin, Y.S. and Ji, Q. (2011): Progress on DNA quantification in estimation of postmortem interval. Fa Yi Xue Za Zhi, 27: 47-49.

Liu, R.M.; Gao, L.; Choi, J. and Forman, H.J. (1998): Gammaglutamylcysteine synthetase: mRNA stabilization and independent subunit transcription 
by 4-hydroxy-2-nonenal. Am J Physiol, 275: 861-869.

Madea, B. and Musshoff, F. (2007): Postmortem biochemistry. Forensic Sci Int, 165: 165-171.

Montgomery, H.A.C. and Dymock, J.F. (1961): The determination of nitrate in water. Analyst, 86: 414416.

Munoz, B.J.I.; Febrero-Bande, M. and Cadarso- Suarez, C. (2008): Flexible regression models for estimating postmortem interval (PMI) in forensic medicine. Stat Med, 27: 5026-5038.

Niki, E.; Yoshida, Y.; Saito, Y. and Noguchi, N. (2005): Lipid peroxidation: mechanisms; inhibition; and biological effects. Biochem Biophys Res Commun, 338(1): 668-676.

Nishikimi, M.; Appaji, N. and Yogi, K. (1972): The occurrence of superoxide anion in the reaction of reduced phenazine methosulphate and molecular oxygen. Biochem Bioph Res Common, 46: 849-854.

Ohkawa, H.; Ohishi, N. and Yagi, K. (1979): Assay for lipid peroxides in animal tissues by thiobarbituric acid reaction. Anal Biochem, 95(2): 351-358.

Ozturk, C.; Sener, M.T.; Sener, E.; Yilmaz, I.; Akcay, F.; Ucuncu, Y. and Suleyman, H. (2013): The investigation of damage in the muscle tissue with the oxidant/antioxidant balance and the extent of postmortem DNA damage in rats. Life Sci J, 10(3):16311637.

Poloz, Y.O. and O'Day, D.H. (2009): Determining time of death: temperature-dependent postmortem changes in calcineurin $\mathrm{A}$; MARCKS; CaMKII; and protein phosphatase $2 \mathrm{~A}$ in mouse. Int $\mathrm{J}$ Legal Med, 123(4): 305-314.

Prieto-Castelló, M.J.; Hernández del Rincón, J.P.; Pérez-Sirvent, C.; Alvarez-Jiménez, P.; PérezCárceles, M.D.; Osuna, E. and Luna, A. (2007): Application of biochemical and X-ray diffraction analyses to establish the postmortem interval. Forensic Sci Int, 172: 112-118.

Rahman, T.; Hosen, I.; Islam, M.M.T. and Shekhar, H.U. (2012): Oxidative stress and human health. Advances in Bioscience and Biotechnology, 3: 997-1019.

Sampaio-Silva, F.; Magalhaes, T.; Carvalho, F.; Dinis-Oliveira, R.J. and Silvestre, R. (2013): Profiling of RNA degradation for estimation of post morterm interval. PLoS One, 8: 56-70.

Scarpelli, D.G. and Iannaccone, P.M. (1990): Cell death; autolysis and necrosis; In: Anderson's pathology. Eds.: Kissane JM.; Anderson WAD; MO: Mosbey; St. Louis; 9 th ed.: 13.

Sener, M.T.; Suleyman, H.; Hacimuftuoglu, A.; Polat, B.; Cetin, N.; Suleyman, B. and Akcay, F. (2012): Estimating the postmortem interval by the difference between oxidant/antioxidant parameters in liver tissue. Adv Clin Exp Med, 21(6): 727-733.

Sharma, R.; Yang, Y.; Sharma, A.; Awasthi, S. and Awasthi, Y.C. (2004): Antioxidant role of glutathione S-transferases: protection against oxidant toxicity and regulation of stress-mediated apoptosis. Antioxid Redox Signal, 6(2): 289-300. 
Sharma, R.K. and Agarwal, A. (2004): Role of reactive oxygen species in gynecologic diseases. Reproductive medicine and Biology, 4: 177-199.

Szymonik-Lesiuk, S.; Czechowska, G.; Stryjecka-Zimmer, M.; Słomka, M.; Madro, A.; Celiński, K.; Wielosz, M. (2003): Catalase; superoxide dismutase; and glutathione peroxidase activities in various rat tissues after carbon tetrachloride intoxication. J Hepatobiliary Pancreat Surg, 10(4):309-315.

Tumram, N.K.; Bardale, R.V. and Dongre, A.P. (2011): Postmortem analysis of synovial fluid and vitreous humour for determination of death interval: A comparative study. Forensic Sci Int, 204: 186190.

Vass, A.A. (2011): The elusive universal post-mortem interval formula. Forensic Sci Int, 204: 3440.

Wei, Y.H.; Lu, C.Y.; Wei, C.Y.; Ma, Y.S. and Lee, H.C. (2001):
Oxidative stress in human aging and mitochondrial diseaseconsequences of defective mitochondrial respiration and impaired antioxidant enzyme system. Chinese Journal of Physiology, 44: 1-11.

Yao, J.K.; Leonard, S. and Reddy, R.D. (2004): Increased nitric oxide radicals in postmortem brain from patients with schizophrenia. Schizophr Bull, 30(4): 923-934.

Yilmaz, M.; Isaoglu, U.; Cetin, N.; Turan, M.I.; Suleyman, B.; Gocer, F.; Ozgeris, F.B. and Suleyman, H. (2012): Effects of adrenalin on ovarian injury formed by ischemia reperfusion in rats. Lat Am J Pharm, 31(7): 1032-1037.

Young, S.T.; Wells, J.D.; Hobbs, G.R. and Bishop, C.P. (2013): Estimating postmortem interval using RNA degradation and morphological changes in tooth pulp. Forensic Science International, 229: 163.e1-163.e6. 


\title{
تقدير الفترة المبكرة بعد الوفاة عن طريق التغيرات الكيميائية الحيوية في مخ الفخدان

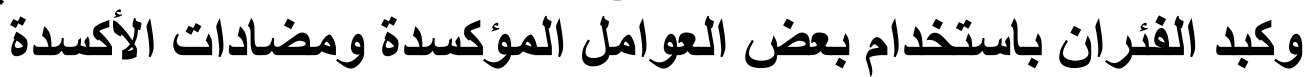

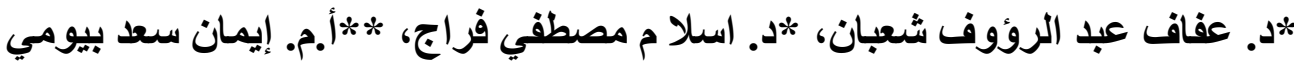

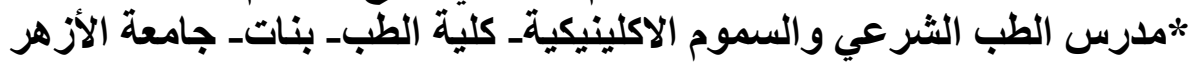

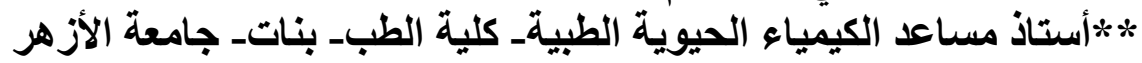

يعد التقدير الدقيق لفترة ما بعد الوفاة من اهم أولويات الطب الثر عي. وتحدث بعد الوفاة اضطر ابات كيميائية حيو ية تتمثل في تغير ات في العيق العو امل المؤكسدة ومضاد العنادات الأكسدة.

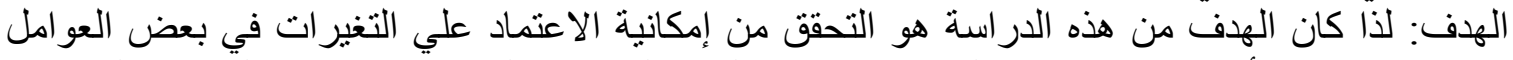

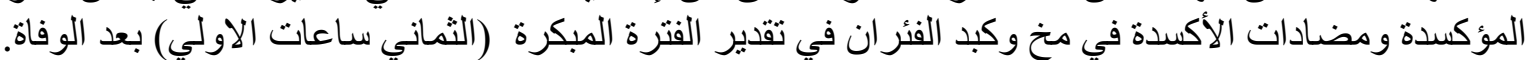

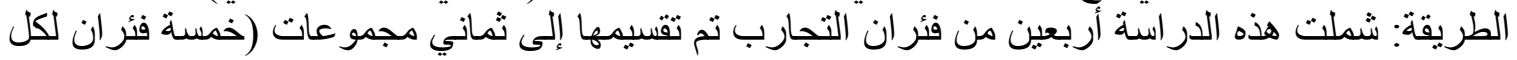

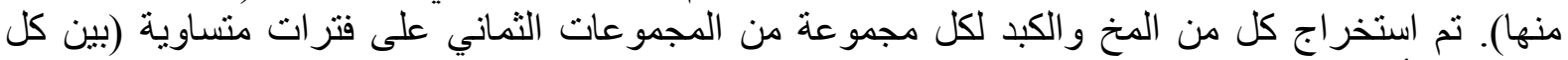

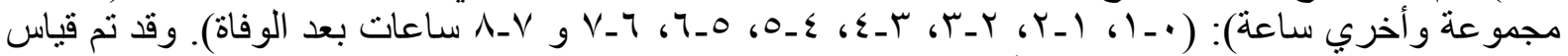

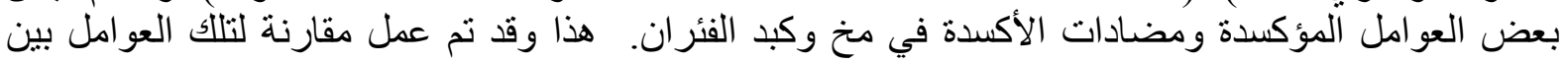

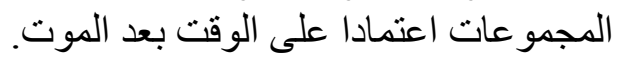

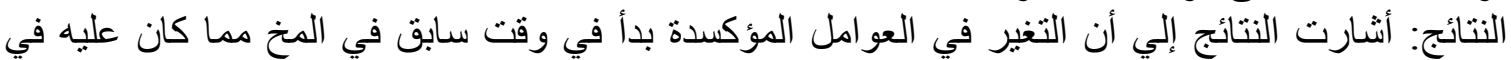

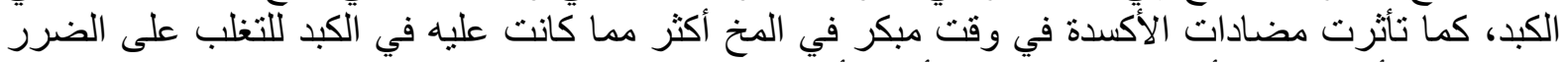

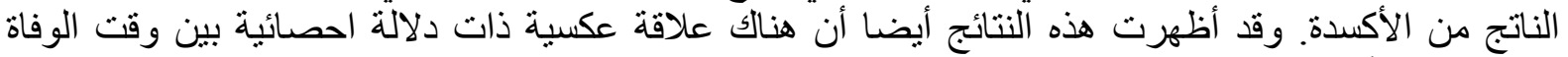

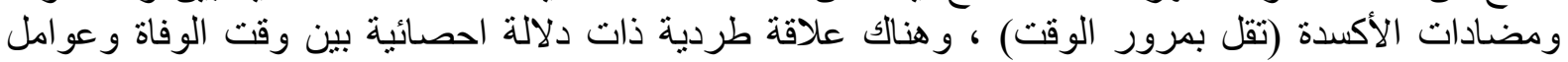

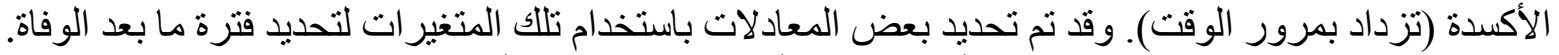

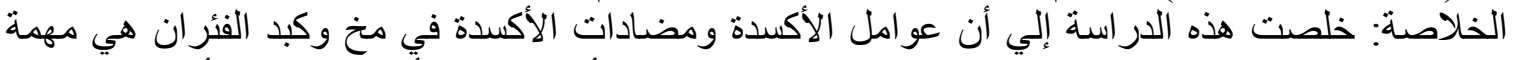

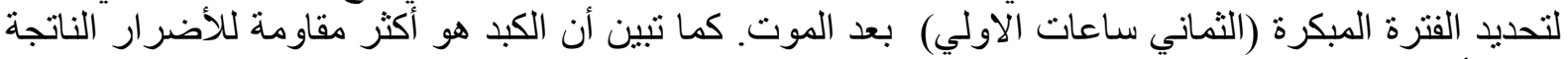

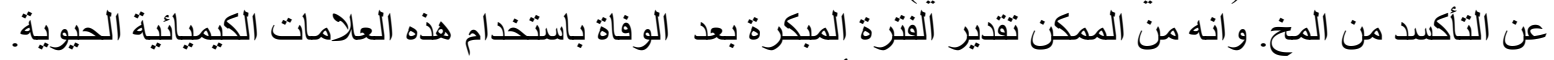

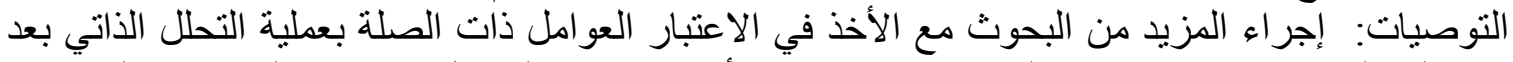

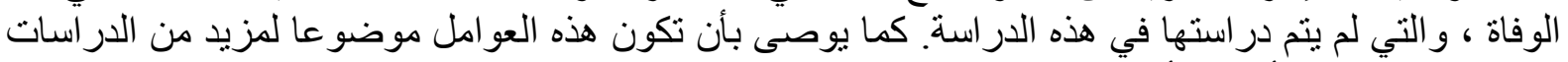

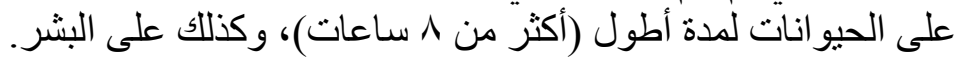

